Jpn. J. Limnol., 49, 2, 129-134, 1988.

\title{
Note \\ Direct Observation of Bacterial Attachment to Immersed Glass Slide under Epifluorescence Microscopy
}

\author{
Kenji Kato, Su-wan $\mathrm{OH}$ and Tokio Okino
}

\begin{abstract}
Bacterial attachment to the solid surface in the littoral zone of a eutrophic lake was studied by a simple method using a glass slide under epifluorescence microscopy with acridine orange staining. The initial rate of bacterial attachment was around $1 \times 10^{5} \mathrm{cell} \cdot \mathrm{cm}^{-2} \cdot \mathrm{hr}^{-1}$, and the attached bacterial number amounted to about $10^{6}$ cells $\cdot \mathrm{cm}^{-2}$ in $24 \mathrm{hr}$ during experiments in June in Lake Suwa. The contribution of attached bacteria with large cell size and that of dividing cells to the total attached bacteria showed a tendency to increase with immersion time.
\end{abstract}

Key words : bacteria, attachment, epifluorescence microscopy.

Although free-living bacteria are usually the predominant form of planktonic bacteria in aquatic environments, adhesion of bacteria to the solid surfaces is believed to be an important step for the degradation of organic particles including macrophytes (KATo, 1985). Solid surfaces are supposed to be favorite sites for the growth of bacteria. considering the advantage of attachment to nutrient rich surfaces from diluted bulk waters (BREzNAK et al., 1984). The function of attached bacteria in decomposition and nutrient recycling may be emphasized especially in the littoral zone, where various surfaces of suspended particles, macrophytes and sediment can be found. The present study represents an attempt to estimate the planktonic bacterial attachment to the glass slide submerged in lakewater in order to evaluate microbial function in the matter cycle of the littoral zone.

Epifluorescence microscopy has seen widespread use in aquatic microbial ecology over the past ten years as a direct method for bacterial counting. However, it has mostly been applied to planktonic bacteria which are trapped on polycarbonate filters (Zinimermani and Meyer-Reil, 1974 ; Hobbie et al., 1977). We just applied this method with acridine orange staining to the observation of bacterial attachment to the glass slide with some modifications. The method which we employed is much more simple and direct compared with the former techniques of FLETCHER and LoEB (1979) or PALL. and LoEB (1983).

In the procedure employed, glass slides were washed by soaking in a $10 \%$ nitric acid solution (PORTER and FEIC, 1980) for a few hours and rinsed with particle-free distilled water (PFDW, filtrate of a $0.2 \mu \mathrm{m}$-pore size Nuclepore filter). Then the glass slides held with clips were immersed in in situ lakewater. After exposure to lakewater, the slides were removed and air dried. The slides were then immersed in $0.1 \%$ acridine orange solution for a few minutes. Surplus acridine orange was washed twice with PFDW and then air dried. A part of the sample on the glass slide was covered with a cover glass using immersion oil. Bacteria attached to the surface of glass slide were counted at $\times 1,250$ with an epifluorescence microscope (Olympus BHS-RFK) equipped with a dry objective of $\times 100$. For each slide at least 20 fields of $42 \times 42 \mu \mathrm{m}^{2}$ or more than several hundreds of bacteria were counted. The frequency of dividing cells (FDC. HAciströn et al., 1979) was determined during the counting and bacterial cell size was measured using a micrometer set on the eyepiece.

The employed air drying fixation can be a source of possible errors in the estimation of attached bacterial number, because it took up to $30 \mathrm{~min}$ until the sample had fully dried. Thus, we checked whether this process affects bacterial growth, comparing the employed technique with oven drying and formalin fixation. As far as examined in Lake Suwa on 4 March 1986, there was no large 
Table 1. Comparison of three fixation procedures.

\begin{tabular}{cccc}
$\begin{array}{c}\text { Immersion } \\
\text { period }\end{array}$ & Air dried & Oven dried $^{a}$ & Formalin fixed $^{\prime \prime}$ \\
\hline $5 \mathrm{~min}$ & $0.74 \pm 0.19^{\circ}$ & $1.0 \pm 0.45$ & $0.73 \pm 0.19$ \\
$4 \mathrm{hrs}$ & $1.0 \pm 0.30$ & $0.98 \pm 0.23$ & $1.4 \pm 0.30$ \\
7 & $2.0 \pm 0.60$ & $1.8 \pm 0.23$ & $2.0 \pm 0.30$ \\
24 & $3.2 \pm 1.4$ & $3.6 \pm 1.0$ & $3.2 \pm 0.74$
\end{tabular}

\footnotetext{
a : At 40 C.

$b$; Glass slide was immersed in $2 \%$ formalin for a few minutes, rinsed with PFIWW twice, and then air dried.

c ; $\times 10^{6}$ cells $\cdot \mathrm{cm}^{2}$.
}

difference in the attached bacterial number among the three fixations (Table 1). It was confirmed that the employed fixation technicue was not the source of error in this study. The burning fixation technique, which was usually employed for the fixation of bacteria smeared on the glass slide, was not applied in this study in order to diminish the possible risk of collapse of the attached algal cells by the strong fixation.

We first applied this method in Lake suwa, a shallow eutrophic lake in June 1985, when the number of planktonic bacteria determined by acridine orange direct count using a Nuclepore filter of $0.2 \mu \mathrm{m}$ pore size (Hobint ot al.. 1977) was about $2 \times 10^{7}$ cells $\cdot \mathrm{ml}{ }^{\prime}$ (mean \pm standard deviation were $2.13 \pm 1.36 \times 10^{\gamma}$ cells $\bullet \mathrm{ml}^{1}$ on 10 June and $1.83 \pm 0.84 \times 10^{7}$ cells $\cdot \mathrm{ml}^{1}$ on 2.5 June). Figure 1 shows that the attached bacterial number amounted to over $10^{5}$ cells $\cdot \mathrm{cm}^{2}$ within several hours of immersion with the rate of $0 . \overline{5}-2 \times 10^{5}$ cells $\cdot \mathrm{cm}^{2}$. hr '. As shown in Table 1, however, a case in March evidenced a significant amount of attached bacteria on a glass slide of only is minute immersion, whereas hardly any were observed on the glass slide before immersion in the lake. Between 24 and $48 \mathrm{hr}$ of immersion the attached bacterial number reached $10^{6}$ cells $\cdot \mathrm{cm}^{\prime 2}$ in June in Lake Suwa.

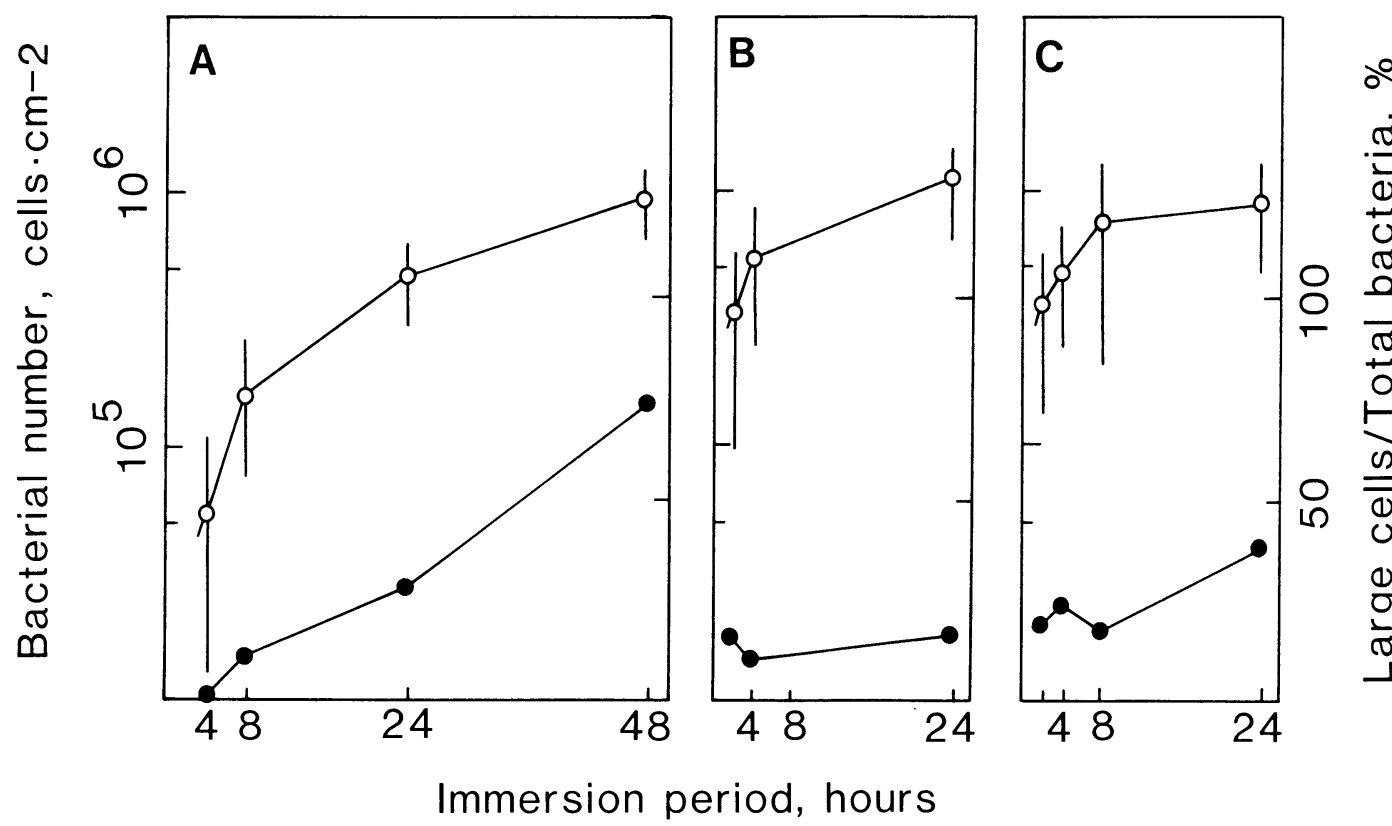

Fig. 1 Increase in number of attached bacteria $(0)$ and the contribution of large cells to total attached bacteria in percent (O). A : (jlass slides were immersed on 10 June. B : 12 June ; C : 25 June. Bars indicate standard deviation in each count. 

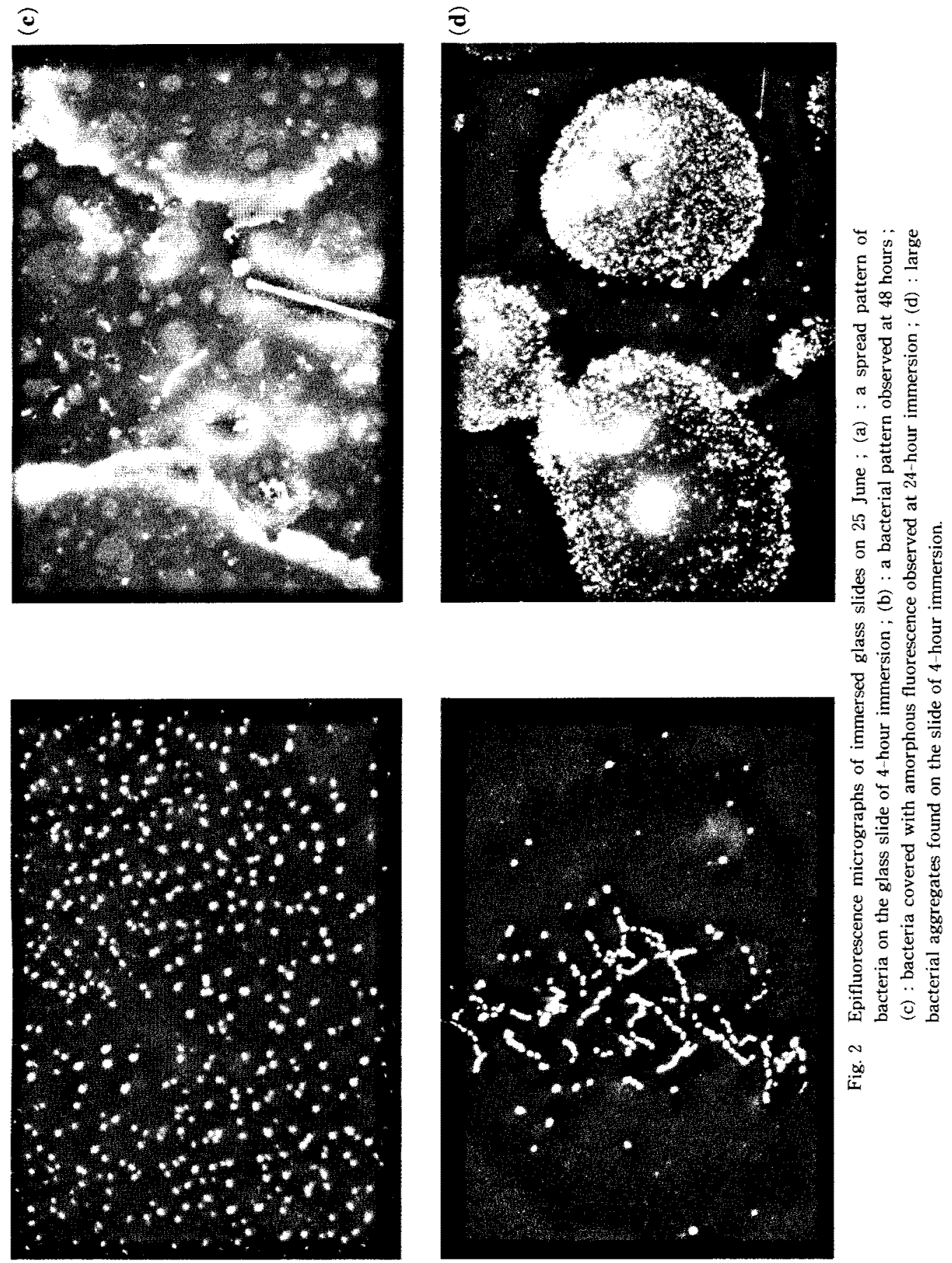

త్

$\widehat{e}$ 
Table 2. Total number of bacteria attached to immersed glass slide and frequency of dividing cells (FDC). Experiment was started on 25 June.

\begin{tabular}{cccc}
\hline $\begin{array}{c}\text { Immersion } \\
\text { period } \\
\text { (hrs) }\end{array}$ & $\begin{array}{c}\text { Total bacteria } \\
\left(\mathrm{T}, \times 10^{5} \mathrm{cells} \cdot \mathrm{cm}^{-2}\right)\end{array}$ & $\begin{array}{c}\text { Dividing cells } \\
\left(\mathrm{D}, \times 10^{4} \mathrm{cell} \cdot \mathrm{cm}^{-2}\right)\end{array}$ & $\begin{array}{c}\text { FDC } \\
(\mathrm{D} / \mathrm{T}, \%)\end{array}$ \\
\hline 2 & 3.66 & n. d. & n. d. \\
4 & 4.86 & 1.13 & 2.3 \\
8 & 7.71 & 5.10 & 6.6 \\
24 & 9.13 & 18.1 & 19.9 \\
\hline
\end{tabular}

n. d. ; not determined.

Although it is a tentative definition of more than about 0.5 to $1.0 \mu \mathrm{m}$ in length, the contribution of these large bacteria to the total population tended to increase with the immersion period (Fig. 2). The increase in cell size probably provided by the attachment to the solid surface will lead to higher attached bacterial per-cell activity for nutrient scavenging than that of free-living bacteria (Honson et al., 1981 ; PAerl and Merkel, 1982).

The FDC has been proposed as an indicator of bacterial growth rate (HAcistRöm et al., 1979 ; Newell and Christian, 1981). Table 2 shows that the FDC in a bacterial population adsorbed on the glass slide increased significantly at $24 \mathrm{hr}$ of in situ incubation, while the FDC observed at 4 or $8 \mathrm{hr}$ are the number usually counted in this lake (OH, unpublished). This might suggest that bacteria grow at a higher rate on the surface of a glass slide than in bulk waters. The increase in FDC seemed to follow the increase in bacterial cell size as mentioned above.

Microscopic image of attached bacteria on the glass slide observed in June is given in Figure 2. Figure 2(a), (b) show two types of attached bacteria on glass surface : Figure 2 (a) indicates a spread pattern observed for the sample of four hours of immersion. If this is produced by an activity of one or some bacterium/a, they would be a gliding type (NAGATA and WATANABF, 1983). Figure 2(b) is an aggregate, called "Chinese letter" by Hiksu (1984), which we observed at $48 \mathrm{hr}$. After $24 \mathrm{hr}$ of immersion, usually it became difficult in Lake Suwa to count bacteria due to the strong fluorescence from attached algae and fluorescent crystals as shown in Figure 2(c).

Figure $2(\mathrm{~d})$ is a photograph of large bacterial aggregates from the glass slide immersed in lakewater for four hours. Each aggregate contained a strongly fluorescent core substance of 20 or $30 \mu \mathrm{m}$ in diameter. If these large aggregates were formed from a bacterium within four hours of immersion, the doubling time for these bacteria would be about $20 \mathrm{~min}$, probably a Guiness Record for natural bacteria. Otherwise, the aggregates would have already been formed in water and floated as colonies. Although it was suggested that the growth rate of bacteria on the surface of glass slide might be larger than that in bulk water, the estimated doubling time of $20 \mathrm{~min}$ seems to be too short compared with the shortest doubling time of a few hours for planktonic bacteria observed in this lake (KATO, unpublished). Thus the latter explanation is more plausible in this case.

Bacterial attachment to the solid surface of a glass slide and their behaviour on it was easily and directly observed with epifluorescence microscopy by the method described here.

\section{Acknowledgements}

We thank two journal-appointed reviewers for critical assessment of the manuscript. This research was supported by a Grant-in-Aid for Environmental Science of The Ministry of Education, Science and Culture, Japan, No. 61030039.

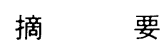

落射螢光顕微鏡によるバクテリアの スライドグラスへの付着現象の観察

湖水中のバクテリアの固体表面（スライドグラス） への付着の様子をアクリジンオレンジによる螢光染色 法を応用して観察した。6月に諏訪湖で観測した結果 では，バクテリアのスライドグラスへの付着の初期速 度は，抢よそ $1 \times 10^{5} \mathrm{cells} \cdot \mathrm{cm}^{-2} \cdot \mathrm{hr}^{-1}$ で, 24 時間後に は $1 \mathrm{~cm}^{2}$ あたり $10^{6}$ のバクテリアが認められた。付着バ クテリア群集の中に，大型の細胞や分裂中の紐胞の占 める割合が, 時間と共に增大寸る傾向がうかがわれた。 


\section{References}

BREZNAK, J. A. et al. (1984) : Activity on surfaces. p.203-221. In K. C. Marshall (ed.), Microbial adhesion and aggregation. Springer-verlag.

Fletcher, M. and G. I. Loeis (1979) : Influence of substratum characteristics on the attachment of marine Pseudomonad to solid surfaces. Appl. Environ. Microbiol., 37 : 67-72.

Hagströn, A., U. Larsson, P. Horsteit, and S. NoR.MARK (1979) : Frequency of dividing cells, a new approach to the determination of bacterial growth rates in aquatic environments. Appl. Environ. Microbiol., 37 : 805-812.

HiRSCH, P. (1984) : Microcolony formation and consortia. p.373-393. In K. C. Marshall (ed.), Microbial adhesion and aggregation. Springer Verlag.

Hobbie, J. E., R. J. Daley, and S. Jasper (1977): Use of Nuclepore filters for counting bacteria by fluorescence microscopy. Appl. Environ. Microbiol., 33 : 1225-1228.

Honson, R. E., A. E. Maccubbin, and L. R. Pomeroy (1981) : Dissolved adenosine triphosphate utilization by free-living and attached bacterioplankton. Mar. Biol., 64: 43-51.

KATO, K. (1985) : A concept on the structure and function of bacterial community in aquatic ecosystems. Verh. Internat. Verein. Limnol. $22: 2739-2743$.

Nagita, T. and Y. Watanabe (1983): Observations on the colonial pattern of periphytic bacteria in a river. Physiol. Ecol. Japan, 20 : 71-79.

Newell, S. Y. and R. R. Curistian (1981):
Frequency of dividing cells as an estimator of bacterial productivity. Appl. Environ. Microbiol., 42 : 23-31.

PAerL, H. W. and S. M. Merkel. (1982) : Differential phosphorous assimilation in attached vs. unattached microorganisms. Arch. Hydrobiol., $93: 125-134$.

Paul, J. H. and G. I. Loek (1983) : Improved microfouling assay employing a DNA-Specific fluorochrome and polystyrene as substratum. Appl. Environ. Microbiol., $46: 338-343$.

Porter, K. C. and Y. S. Feic (1980) : The use of DAPI for identifying and counting aquatic microflora. Limnol. Oceanogr., 25 : 943-948.

ZimmermanN, R. and L. A. Meyer-Reil. (1974) : A new method for fluorescence staining of bacterial populations on membrane filters. Kiel Meeresforsch., 30 : 24-27.

(著者：加藤憲二, 信州大学医療技術短期大学部, $\bar{\top}$ 390 松本市旭 3-1-1 ; 吳壽完 ${ }^{*}$, 沖野外輝夫, 信州大学 理学部付属諏訪臨湖実験所, 广 392 諏訪市湖岸通 5-2-4: Kenji Kato, School of Allied Medical Sciences, Shinshu University, 3-1-1 Asahi, Matsumoto 390 ; Su-wan OH, Tokio Okino, Suwa Hydrobiological Station, Shinshu University, 5-2-4 Kogandori, Suwa 392 ; ${ }^{*}$ 現住所: 東京大学海洋研究 所, 東京都中野区南台; Ocean Research Institute, University of Tokyo, Minamidai, Nakano-ku, Tokyo 164.)

Received : 27 October 1987 Accepted : 9 February 1988 